\title{
CALL FOR PAPERS \\ SOCIETY FOR COMPUTERS IN PSYCHOLOGY
}

The 14th annual meeting of the Society for Computers in Psychology will be held on November 7, 1984 (the day before the Psychonomic Society meeting), in San Antonio, Texas. The deadline for submission of papers, symposia, and posters is July 1, 1984. Further information may be obtained from, and submissions sent to:

\author{
Walter Schneider \\ Department of Psychology \\ University of Illinois \\ 603 E. Daniel Street \\ Champaign, IL 61820
}

(217)333-6819

\section{COMPUTER CONFERENCE STUDENT PAPER COMPETITION}

The Society for Computers in Psychology will continue to sponsor an award for the outstanding student paper submitted for presentation at the annual meeting. Although the primary emphasis of the conference is the use of computers in on-line experimental applications, student papers in any area of application of computers to psychology are welcome. Papers may be theoretical, experimental, or applied in approach. Eligibility is open to students currently enrolled in undergraduate or graduate courses, or students who graduated in 1984 and have done the work as part of a course, thesis, or other student research project. All papers submitted for the conference (including those multiply authored) in which the major contribution has been made by a student are eligible for consideration and will be considered for presentation at the conference and subsequent publication. The outstanding student paper will be presented at the 1984 conference and published in the Computer Conference Proceedings. Also, the author will receive a complimentary 1-year membership in the Society for Computers in Psychology, a complimentary 1-year subscription to Behavior Research Methods, Instruments, \& Computers, and a $\$ 50$ cash prize.

\section{DEADLINE FOR PAPERS: JULY 1, 1984}

Eligible papers should be submitted in quadruplicate. A cover sheet should include the author's name, mailing address, telephone number, and academic affiliation, a 50-word abstract, and a note stating that the paper is to be considered for the student award. These materials should be sent to:

\author{
Walter Schneider \\ Department of Psychology \\ University of Illinois \\ 603 E. Daniel Street \\ Champaign, IL 61820
}

